Published in final edited form as:

Expert Rev Anticancer Ther. 2008 May ; 8(5): 799-809. doi:10.1586/14737140.8.5.799.

\title{
Molecular Mechanisms of Head and Neck Cancer
}

\author{
Amit M Deshpande, Ph.D. and David T Wong, D.M.D., D.M.Sc \\ University of California Los Angeles, Dental Research Institute, School of Dentistry, 73-017 CHS, \\ 10833 Le Conte Ave, Los Angeles, CA 90095-1668, Phone: (310) 206-3048, Fax: (310) 825-7609 \\ Amit M Deshpande: ; David T Wong: dwong@dentistry.ucla.edu
}

\begin{abstract}
Background-With a global incidence rank of eight and a significant portion of head and neck malignancies ( $90 \%$ ), oral squamous cell carcinoma (OSCC) poses a major health risk and is one of the leading cause of mortality in developing nations [1]. Distribution of the incidence of OSCC varies across the world with south-central Asia and Africa leading, followed by eastern and central Europe, and to a lesser extent Australia, Japan, and the United States. Over the past few years there has been a drastic increase in the incidence of oral cancer in most parts of the world [2]. In the United States alone, with about 17 new cases/100,000, oral cancer is the fifth most common and sixth leading cause of cancer-related mortality per year [3]. While men tend to have a higher incidence of OSCC $(6.6 / 100,000)$ compared to women $(2.9 / 100,000)$, there is an equal mortality rate between the sexes $(50 \%)$.
\end{abstract}

\section{Standard of care}

\section{Diagnosis}

Early diagnosis and treatment of precancerous lesions, which tend to last for many years before advancing to a highly malignant metastatic form, has been shown to result in an increased 5year survival rate. In spite of the advances in the diagnostics and therapeutics, specially of early stage disease (stages I and II), the overall 5-year survival rate for oral cancer remains at about $50 \%[35,36]$. This has been attributed to either identification of lesions at advanced stages of the disease, or, metastases and/or second tumors arising in patients following resection or treatment of the primary tumor.

Significant advances have been made in recent years in diagnosis and treatment of local primary OSCC tumors. Diagnoses techniques include the use of Toluidine Blue, which stains the nuclei of rapidly dividing cells in malignant lesions dark blue, and indirect mirror examination of the oral, nasopharyngeal and laryngopharyngeal regions, Photodynamic diagnosis using 5aminolevulinic acid (5-ALA) [37,38], autofluorescence, using flavin based staining for healthy tissue, and CT scans are routinely used to identify extent of spread of the primary tumor as well as possible metastases [39].

\section{Treatment}

Depending on the stage and extent of disease, treatment options for OSCC include surgery, radiotherapy, chemotherapy, and various combinations of these. Treatment options for OSCC are selected based on numerous factors including stage, grade and location of the tumor and, health and age of the patient. Newer treatment options include immunotherapy and gene therapy, both of which are in the initial stages of validation. Numerous molecular targets are also being explored for developing drugs for treatment of OSCC. These approached are preferred over surgical resection, a standard approach for treatment of OSCC tumors, specially since it leaves the patient disfigured and in need for follow up reconstructive surgery. Improvements in treatment of primary OSCC have been achieved with combination therapy, 
wherein radiation and chemotherapy have been combined, either together, or with moleculartargeted therapies. These together have improved 3-year survival rates from $~ 15 \%$ to $35-50 \%$. Combinations of radiation and chemotherapy (using taxanes) have increased survival rates to about $70 \%$ [40].

\section{Molecular Genetics}

Understanding the molecular and genetic alterations in the pathogenesis of OSCC will help elucidate the mechanisms involved in tumor formation as well as identify potential targets for improved treatment of OSCC. OSCC formation occurs through accumulation of multiple genetic alterations. OSCC formation, which is a multistep process, is initiated by chemical insults to the normal oral epithelium by carcinogens including tobacco, alcohol, etc. This results in genetic alterations and formation of preneoplastic lesions and eventually OSCC. These changes are characterized by increasing genetic instability, aneuploidy, increased dysplasia, altered expression of cell surface markers, loss of cellular organization, and eventually invasive penetration through the basement membrane. Though multiple pathways, which promote cell proliferation, cell survival, and/or transformation capabilities, have been identified understanding of molecular pathway cooperativity involved in OSCC tumorigenesis is still lacking.

\section{Etiology and risk factors}

Oral cancer includes the tumors localized to the oral cavity and includes tumors arising on the tongue, buccal mucosa, lips, hard and soft palate, gums and the base of the mouth [4]. OSCC is frequently associated with high risk behaviours, including, smoking, alcohol consumption, and the use of smokeless tobacco. OSCC risk is additive and has been shown to be higher in patients with a history of alcoholism and smoking compared to normal population and to independent effects of smoking or alcohol [5-7].

Additionally, smokeless tobacco usage, including betel leaves, miang, qat, etc., has been shown to cause and/or promote OSCC tumorigenesis.

Human papilloma virus (HPV) has been associated with the genesis of OSCC, specifically a subset of tumors which are localized to the lingual and palatine tonsils within the oropharynx [8]. HPV16 infections have been associated with a 3-6 fold increase in oropharyngeal OSCC risk [9-14]. OSCC incidence arising from HPV infections combined with alcohol or tobacco abuse has not been established due to limitations in sample sizes.

Dietary intake has been shown to have the most significant effect on OSCC compared to any other malignancy. A diet rich in fruits and vegetables has been shown to reduce the risk of OSCC, in patients with and without a history of tobacco and/or alcohol abuse [6,15-22].

Although OSCC is rarely associated with inherited cancer syndromes, a few heritable disorders have been shown to increase the risk of an individual to OSCC. The tumors have a younger age of onset, typically, below 40 years. OSCC have been reported in patients with Fanconi anemia. These patients, who inherit recessive autosomal mutations in genes regulating DNA recognition and repair, show an increased risk of bone marrow failure, leukemia, and solid tumors including OSCC. Fanconi anemia patients have a 500- to 700- fold increased risk of OSCC formation [23-26]. Increased risk of OSCC has also been reported in individuals inheriting functionally inactivating mutations in the CDKN2A gene. Somatic inactivation of this important regulator of cell cycle at the G1-S boundary has also been reported in sporadic OSCC tumors [27-30]. The case for the presence of predisposing genetic factors for OSCC is strengthened by the fact that positive family history increases an individual's risk for OSCC 
by 2 - to 4 - fold. This risk is greater if the affected family member is a sibling (8-fold or more). The risk of second tumors is also higher in these individuals [31-34].

\section{Chemical carcinogenesis and the Ras pathway}

As with most models of epithelial tumorigenesis, chemical carcinogens have been used to induce OSCC formation. The most frequently used inducers include, 9,10-dimethyl-1,2benzanthracene (DMBA) and 4-nitroquinoline-1-oxide (4NQO) [41-43]. The administration of $4 \mathrm{NQO}$ through drinking water or via local application in experimental animals has been shown to faithfully replicate the human disease progression from preneoplastic lesions to fully blown tumors. And similar to the human disease, this model induces hyperplasia and dysplastic lesions with long-term administration of small doses of carcinogen. Application of the 4NQO has been shown to result in polyploidy, activation of oncogenes, including Ha-Ras, and loss of function for tumor suppressor genes, including p53, and cell adhesion molecules, E- and Pcadherins [44-47].

\section{Genetic alteration in preneoplastic lesions}

A few genomic regions of loss have been implicated as early events in the formation of preneoplastic lesions. These include regions on chromosomal arms $9 p, 17 p$ and $3 p$. The genes involved in early genesis of OSCC, which map to these regions of frequent loss, include $p 14^{A R F}$ and $p 16^{I N K 4 a}$ on 9p21, TP53 on 17p13, and FHIT on chromosome 3p14. Deletions of $4 q, 6 p, 8 p, 13 q$, and $14 q$ and amplification of $7 p$ and $11 q$ have also been reported in OSCC at later stages of tumor formation [48-52].

p16 INK4a/p14ARF locus-The p16 gene is involved in the regulation of the RB-pathway. p16 inhibits the activity of Cyclin D/CDK-4, -6 complexes to prevent the phosphorylation of $\mathrm{pRB}$, and hence preventing cell cycle progression. Product of the alternate transcript, $p 14^{A R F}$, interacts with MDM2, which is involved in degradation of TP53. Loss of the INK/ ARF locus results in deregulation of both, p53 and pRB, pathways and hence uncontrolled cell proliferation [53].

TP53-Normal TP53 function is lost in almost all tumors, either through mutations or genomic deletions of the gene, or through up-regulation of negative regulators of TP53 function. Loss of heterozygosity for the TP53 locus has been reported in about 60\% of OSCC [54-57]. It is almost impossible to detect TP53 expression in normal tissue due to a high turnover of the TP53 protein. This expression pattern of TP53 is altered in tumor tissue wherein mutant forms of TP53, which are highly stable, are readily detected by immunohistochemical analyses. Approximately 50\% OSCC tumors stain positive for TP53 [58,59]. Another member of the p53 family implicated in OSCC genesis and progression is P63. P63 is thought to play a role in differentiation of keratinocytes and epithelial cells. Decreased P63 expression in OSCC, in the context of TP53 expression, has been shown to correlate with increased metastatic load and decreased overall survival [59].

Cyclin D1-CDK4/6-Cyclin D complexes are involved in phosphorylation of pRB, a major regulator of the G1/S transition of cell cycle. Phosphorylation of pRB results in release of bound $\mathrm{E} 2 \mathrm{~F}$ transcription factors, premature transition into S-phase, and, a resultant nondiploidy of DNA. Amplification of the Cyclin D1 locus, 11q13, has been reported in numerous epithelial malignancies. Approximately $30-50 \%$ of OSCC tumors show and amplification and/ or increased protein expression [60-62].

EGFR and EGFR signaling-Another region of amplification is $7 \mathrm{p} 12$. This amplicon encodes the EGFR gene that, along with its ligand Transforming growth factor alpha (TGF$\alpha$ ), has been shown to be amplified and overexpressed in 80-90\% of OSCC tumors [63-66]. 
In addition, EGFR signaling has been shown to promote metastases [63]. High EGFR expression has been shown to be present even in 'healthy' tissues surrounding the tumor lesions in cancer patients compared to normal population [67].

EGFR encodes a transmembrane receptor that is activated by its ligands EGF and TGF- $\alpha$. Activation of EGFR by its ligands results in homodimerization of the receptor and subsequent activation of tyrosine kinase via the intracellular domain of the receptor. This activates the downstream MAP kinase signaling cascade and promotes cell proliferation and angiogenesis, and inhibits apoptosis. Phosphorylation mediated activation of MEK and ERK proteins results in their translocation into the nucleus and activation of a number of transcription factors which control cell proliferation, migration and differentiation $[68,69]$.

TGF- $\beta$ pathway-The TGF- $\beta$ pathway has been shown to play a significant role during embryogeneis, organogenesis, and in tumor formation, specially in epithelial tumorigenesis. These effects of the TGF- $\beta$ pathway have been attributed to the positive, as well as negative effects of TGF- $\beta$ and its down stream effector molecules on cell proliferation, survival, and differentiation. The TGF- $\beta$ cytokines signal predominantly through the serine-threonine kinase family of receptors, TGF- $\beta$ receptors type I and type II (T $\beta$ RI and T $\beta$ RII, respectively), and downstream effector molecules including SMAD proteins -2, - 3, -4, and -7. Alterations in expression or activity of individual members of the TGF- $\beta$ pathway has been detected not only in multiple epithelial tumors, but also in tumors influenced by their epithelial environment. These include carcinomas of the breast, prostate, gastrointestinal tract (stomach, colon, and rectum), lung, cervix, liver, and skin. Although mutations of the individual members of the TGF- $\beta$ pathway have been identified in OSCC and other epithelial tumors, they are relatively rare [70-74]. A more frequent event is a reduction in the expression of T $\beta R I I$ [75]. This is evident in knockout mouse models where there is an increase in the penetrance and rate of tumor formation, and metastases in various tissues [76-84]. TRRII expression has been shown to be affected by: a) mutations in the promoter region of the gene [85,86]; b) activated oncogene activity, including Cyclin D1, and Ras [87,88]; c) epigenetic regulation [89]. Thus, signaling via the T $\beta$ RII has been suggested to have tumor suppressive function in the tumorigenic process. Reduced expression and hence attenuation of T $\beta$ RII signaling will result in increased resistance to TGF- $\beta$ mediated growth suppression, increased cell proliferation, decreased differentiation and increased transformation capacity of the tumor cells [87,90,91].

In oral cancer, the above observations hold true, with a majority of OSCC tumors, both primary and second, exhibiting reduced expression of T $\beta$ RII, and only a few tumors showing mutations in the members of the TGF- $\beta$ pathway [92]. Numerous studies have shown that most primary oral squamous cell carcinomas retain TGF- $\beta$ signaling. This signaling diminishes as the disease progresses from carcinoma to metastases. During this transition a significant decrease in T $\beta$ RII expression, resulting from down-regulation of gene expression and not mutations, has been observed [75]. Understanding the effects of this decrease in TGF- $\beta$ signaling and identifying the molecules involved in modulation of cell cycle, proliferation, survival and differentiation in response to TGF- $\beta$ will help in developing novel targeted therapies for treatment of oral cancer.

Multiple chromosomal abnormalities have been reported in OSCC by cytogenetic and spectral karyotype analyses. Frequent loss of heterozygosity has been reported for chromosome 18 in OSCC implicating SMAD-2 and -4 as important players in the tumorigenic process [93]. Mutations, though relatively rare, have also been identified in the SMAD genes and other regulators of the TGF- $\beta$ pathway in primary OSCC tumors and cell lines [75,92,94-97].

CDK2AP1-Also known as $p 12^{C D K 2 A P 1}$ and Deleted in Oral Cancer -1 (DOC-1), this gene was identified by subtractive hybridization from a hamster oral cancer model [98]. CDK2AP1, 
a novel cell cycle regulator, has been shown to regulate cell cycle by interacting with CDK2 and preventing phosphorylation of $\mathrm{pRB}$, thus rendering $\mathrm{pRB}$ active and able to regulate cell cycle [99]. CDK2AP1 has also been shown to interact with DNA polymerase- $\alpha /$ primase and reduce its activity [100]. This interaction affects the initiation, but not elongation step of DNA replication. Although an exact mechanism is not known, it is hypothesized that CDK2AP1 inhibits DNA polymerase- $\alpha /$ primase activity either through direct interaction or through its interaction with CDK2. Reduced or absent expression of CDK2AP1 has been demonstrated in about $60 \%$ of human oral cancer cell lines and tumor samples [101-103]. CDK2AP1 is also a downstream target for the TGF- $\beta$ pathway. There is a significant correlation of reduced T $\beta$ RII expression and CDK2AP1 expression [104]. Thus, CDK2AP1 is a common link between two pathways, the pRB pathway and the TGF- $\beta$ pathway, both of which are affected in the process of OSCC tumorigenesis. Figueiredo et al explored this advantage to use recombinant DNA to re-express CDK2AP1 in OSCC tumors in murine models and showed successful tumor regression [105].

Angiogenesis and vasculogenesis-Blood vessel formation is a critical step in providing nutritional support for tumor growth. Vascular Endothelial Growth Factor (VEGF) is a potent inducer of blood vessel formation and is upregulated in almost all tumors. 10-20\% of dysplastic oral lesions progress to an invasive phenotype. This is accompanied by increase in blood vessel formation and increased blood supply. Increased expression of VEGF is seen in OSCC through all stages of disease progression [106-108]. Other factors that promote blood vessel formation and endothelial cell migration include, prostaglandin $\mathrm{E} 2\left(\mathrm{PGE}_{2}\right)$ and TGF$\beta$ are often overexpressed by tumor cells [109-113]. COX-2 inhibition has been shown to be effective in controlling OSCC cell proliferation and this is shown to be mediated specifically through the inhibition of $\mathrm{PGE}_{2}$.

In addition to angiogenesis, the embryonic phenomenon of vasculogenesis has also been described in the OSCC tumorigenic process. Pak and coworkers have demonstrated an increase in the number of CD34+ progenitor cells in human OSCC tumors [114]. These cells have a capacity to develop into cells that contribute to the tumor vasculature $[115,116]$.

Other genes $-\mathrm{p} 27^{\mathrm{KIP}}$ is a negative regulator of $\mathrm{G} 1 / \mathrm{S}$ transition and functions to regulate cell cycle progression by sequestration and inhibition of the Cyclin D/CDK-4, -6 complex. p27 is expression also associated with the differentiation status of OSCC tumors with welldifferentiated tumors showing positive reactivity for $\mathrm{p} 27$ and less differentiated tumors showing low of no p27 expression. Expression of p27 is downregulated early in OSCC [117, 118]. E-Cadherin, a membrane associated protein, is required for contact inhibition of cell proliferation and cell growth. Loss of E-Cadherin expression due to promoter hypermethylation has been correlated with poor prognoses of oral cancer patients [119-121].

\section{Expert commentary}

Although progress has been made in the areas of diagnostics and therapeutics of OSCC, second tumors and metastases still remain a cause for low 5-year survival and high rates of morbidity and mortality. Combination radiation and chemotherapy approaches have seen improvement in the overall survival of stage I and II patients, but satisfactory treatment options for advanced disease still remain to be achieved. Thus, there is a desperate need for new approaches in cancer treatment. Gene therapy strategies are being tested and in combination with chemotherapy and radiation therapy will prove more powerful. Gene therapy approached are already being tested using adenovirus mediated p53 re-expression, liposome mediated CDK2AP1 re-expression, and antisense inhibition of EGFR [63,105,122]. Inhibitors of specific molecular targets upregulated in the tumorigenic process (EGFR, VEGF, COX-2) are also being tested, either alone or in combination with existing therapies. Trials are ongoing for combination therapies 
in both the US and in Europe. Unless the efficacy of these novel therapeutic approaches in tested and proven in a large cohort, the surgery, chemotherapy and radiation remain as the only options to treat OSCC.

\section{Five-year Review}

A large number of resources are being invested in development of therapies for OSCC. As our understanding of the intersecting nodes of altered molecular pathways involved in OSCC genesis improves, we believe that therapeutic approach for this disease in the future will be more direct and focused. Thus as our understanding of the fundamental molecular changes improves, so will our ability to treat the disease.

\section{Key Issues}

Oral squamous cell carcinoma is a significant worldwide health burden with about 500,000 cases annually

Second tumors and metastases are the most frequent causes of high mortality in OSCC patients.

Chemotherapy and radiation therapy, only second to surgery, are the current treatment options but are successful only with stage I and II OSCC.

Targeted inhibitors of EGFR and VEGF signaling are currently being tested in clinical trials for treatment of OSCC, but more advances in treatment options and identification of better targets is required.

Better understanding of intersecting nodes of various molecular pathways altered in OSCC is needed to improve target identification.

\section{References}

1. Petersen PE. Strengthening the prevention of oral cancer: the WHO perspective. Community dentistry and oral epidemiology 2005;33(6):397-399. [PubMed: 16262606]

2. Petersen, PE. The World Oral Health Report 2003: continuous improvement of oral health in the 21st century--the approach of the WHO Global Oral Health Programme; Community dentistry and oral epidemiology. 2003. p. 3-23.

3. Jemal A, Murray T, Ward E, et al. Cancer statistics, 2005. CA: a cancer journal for clinicians 2005;55 (1):10-30. [PubMed: 15661684]

4. Funk, GF.; Karnell, LH.; Robinson, RA., et al. Presentation, treatment, and outcome of oral cavity cancer: a National Cancer Data Base report; Head \& neck. 2002. p. 165-180.

5. Blot WJ, McLaughlin JK, Winn DM, et al. Smoking and drinking in relation to oral and pharyngeal cancer. Cancer research 1988;48(11):3282-3287. [PubMed: 3365707]

6. Franco EL, Kowalski LP, Oliveira BV, et al. Risk factors for oral cancer in Brazil: a case-control study. International journal of cancer 1989;43(6):992-1000.

7. Rothman K, Keller A. The effect of joint exposure to alcohol and tobacco on risk of cancer of the mouth and pharynx. Journal of chronic diseases 1972;25(12):711-716. [PubMed: 4648515]

8. Gillison ML, Lowy DR. A causal role for human papillomavirus in head and neck cancer. Lancet 2004;363(9420):1488-1489. [PubMed: 15135592]

9. Hansson BG, Rosenquist K, Antonsson A, et al. Strong association between infection with human papillomavirus and oral and oropharyngeal squamous cell carcinoma: a population-based case-control study in southern Sweden. Acta otolaryngologica 2005;125(12):1337-1344.

10. Herrero R, Castellsague X, Pawlita M, et al. Human papillomavirus and oral cancer: the International Agency for Research on Cancer multicenter study. Journal of the National Cancer Institute 2003;95 (23):1772-1783. [PubMed: 14652239] 
11. Maden C, Beckmann AM, Thomas DB, et al. Human papillomaviruses, herpes simplex viruses, and the risk of oral cancer in men. American journal of epidemiology 1992;135(10):1093-1102. [PubMed: 1321561]

12. Mork J, Lie AK, Glattre E, et al. Human papillomavirus infection as a risk factor for squamous-cell carcinoma of the head and neck. The New England journal of medicine 2001;344(15):1125-1131. [PubMed: 11297703]

13. Schwartz SM, Daling JR, Doody DR, et al. Oral cancer risk in relation to sexual history and evidence of human papillomavirus infection. Journal of the National Cancer Institute 1998;90(21):1626-1636. [PubMed: 9811312]

14. Smith EM, Ritchie JM, Summersgill KF, et al. Age, sexual behavior and human papillomavirus infection in oral cavity and oropharyngeal cancers. International journal of cancer 2004;108(5):766772.

15. Bosetti C, Negri E, Franceschi S, et al. Risk factors for oral and pharyngeal cancer in women: a study from Italy and Switzerland. British journal of cancer 2000;82(1):204-207. [PubMed: 10638990]

16. De Stefani E, Boffetta P, Ronco AL, et al. Dietary patterns and risk of cancer of the oral cavity and pharynx in Uruguay. Nutrition and cancer 2005;51(2):132-139. [PubMed: 15860434]

17. La Vecchia C, Tavani A, Franceschi S, et al. Epidemiology and prevention of oral cancer. Oral Oncol 1997;33(5):302-312. [PubMed: 9415327]

18. Lissowska J, Pilarska A, Pilarski P, et al. Smoking, alcohol, diet, dentition and sexual practices in the epidemiology of oral cancer in Poland. Eur J Cancer Prev 2003;12(1):25-33. [PubMed: 12548107]

19. McLaughlin JK, Gridley G, Block G, et al. Dietary factors in oral and pharyngeal cancer. Journal of the National Cancer Institute 1988;80(15):1237-1243. [PubMed: 3418729]

20. Rajkumar T, Sridhar H, Balaram P, et al. Oral cancer in Southern India: the influence of body size, diet, infections and sexual practices. Eur J Cancer Prev 2003;12(2):135-143. [PubMed: 12671537]

21. Zheng T, Boyle P, Willett WC, et al. A case-control study of oral cancer in Beijing, People's Republic of China. Associations with nutrient intakes, foods and food groups. European journal of cancer 1993;29B(1):45-55. [PubMed: 8180577]

22. Taghavi N, Yazdi I. Type of food and risk of oral cancer. Archives of Iranian medicine 2007;10(2): 227-232. [PubMed: 17367228]

23. Kutler DI, Auerbach AD, Satagopan J, et al. High incidence of head and neck squamous cell carcinoma in patients with Fanconi anemia. Archives of otolaryngology--head \& neck surgery 2003;129(1): 106-112. [PubMed: 12525204]

24. Kutler DI, Wreesmann VB, Goberdhan A, et al. Human papillomavirus DNA and p53 polymorphisms in squamous cell carcinomas from Fanconi anemia patients. Journal of the National Cancer Institute 2003;95(22):1718-1721. [PubMed: 14625263]

25. Rosenberg PS, Greene MH, Alter BP. Cancer incidence in persons with Fanconi anemia. Blood 2003;101(3):822-826. [PubMed: 12393424]

26. Thompson LH. Unraveling the Fanconi anemia-DNA repair connection. Nature genetics 2005;37(9): 921-922. [PubMed: 16132046]

27. Hardisson D. Molecular pathogenesis of head and neck squamous cell carcinoma. Eur Arch Otorhinolaryngol 2003;260(9):502-508. [PubMed: 12736744]

28. Sun S, Pollock PM, Liu L, et al. CDKN2A mutation in a non-FAMMM kindred with cancers at multiple sites results in a functionally abnormal protein. International journal of cancer 1997;73(4): 531-536.

29. Yarbrough WG, Aprelikova O, Pei H, Olshan AF, Liu ET. Familial tumor syndrome associated with a germline nonfunctional p16INK4a allele. Journal of the National Cancer Institute 1996;88(20): 1489-1491. [PubMed: 8841025]

30. Yu KK, Zanation AM, Moss JR, Yarbrough WG. Familial head and neck cancer: molecular analysis of a new clinical entity. The Laryngoscope 2002;112(9):1587-1593. [PubMed: 12352668]

31. Bongers V, Braakhuis BJ, Tobi H, Lubsen H, Snow GB. The relation between cancer incidence among relatives and the occurrence of multiple primary carcinomas following head and neck cancer. Cancer Epidemiol Biomarkers Prev 1996;5(8):595-598. [PubMed: 8824360] 
32. Copper MP, Jovanovic A, Nauta JJ, et al. Role of genetic factors in the etiology of squamous cell carcinoma of the head and neck. Archives of otolaryngology--head \& neck surgery 1995;121(2): 157-160. [PubMed: 7840922]

33. Foulkes WD, Brunet JS, Sieh W, et al. Familial risks of squamous cell carcinoma of the head and neck: retrospective case-control study. BMJ (Clinical research ed 1996;313(7059):716-721.

34. Goldstein AM, Blot WJ, Greenberg RS, et al. Familial risk in oral and pharyngeal cancer. European journal of cancer 1994;30B(5):319-322. [PubMed: 7703800]

35. Massano J, Regateiro FS, Januario G, Ferreira A. Oral squamous cell carcinoma: review of prognostic and predictive factors. Oral surgery, oral medicine, oral pathology, oral radiology, and endodontics 2006;102(1):67-76.

36. Okamoto M, Nishimine M, Kishi M, et al. Prediction of delayed neck metastasis in patients with stage I/II squamous cell carcinoma of the tongue. J Oral Pathol Med 2002;31(4):227-233. [PubMed: 12076326]

37. Driemel O, Dahse R, Berndt A, et al. High-molecular tenascin-C as an indicator of atypical cells in oral brush biopsies. Clinical oral investigations 2007;11(1):93-99. [PubMed: 17111122]

38. Remmerbach TW, Weidenbach H, Pomjanski N, et al. Cytologic and DNA-cytometric early diagnosis of oral cancer. Anal Cell Pathol 2001;22(4):211-221. [PubMed: 11564897]

39. de la Torre, J. eMedicine. 2006. Head and Neck Cancer: Squamous Cell Carcinoma. (Ed.^(Eds)

40. Awada A, Ismael G. The challenging integration of platinum compounds, taxanes, and moleculartargeted therapies in the multidisciplinary treatment of squamous cell carcinoma of the head and neck. Current opinion in oncology 2007;19(3):177-179. [PubMed: 17414633]

41. Dayan D, Hirshberg A, Kaplan I, Rotem N, Bodner L. Experimental tongue cancer in desalivated rats. Oral Oncol 1997;33(2):105-109. [PubMed: 9231167]

42. Vered M, Yarom N, Dayan D. 4NQO oral carcinogenesis: animal models, molecular markers and future expectations. Oral Oncol 2005;41(4):337-339. [PubMed: 15792604]

43. Wallenius K, Lekholm U. Oral cancer in rats induced by the water-soluble carcinogen 4-nitrochinoline N-oxide. Odontologisk revy 1973;24(1):39-48. [PubMed: 4514062]

44. Osugi Y. p53 expression in various stages of 4-nitroquinoline 1-oxide induced carcinoma in the rat tongue. Journal of Osaka Dental University 1996;30(1-2):29-35. [PubMed: 9485768]

45. Sakaki T, Tamura I, Kadota H, Kakudo K. Changing expression of E- and P-cadherin during rat tongue carcinogenesis induced by 4-nitroquinoline 1-oxide. J Oral Pathol Med 2003;32(9):530-537. [PubMed: 12969227]

46. Tanuma J, Hiai H, Shisa $\mathrm{H}$, et al. Carcinogenesis modifier loci in rat tongue are subject to frequent loss of heterozygosity. International journal of cancer 2002;102(6):638-642.

47. Yuan B, Hu LH, Lentsch EM, Shum-Siu A, Hendler FJ. Consistent allelic loss on mouse chromosome 7 distal to tyrosinase in 4-nitroquinoline-1-oxide-induced oral cavity tumors with loss of heterozygosity at Ha-ras-1. Molecular carcinogenesis 1997;19(1):8-16. [PubMed: 9180923]

48. Califano J, van der Riet P, Westra W, et al. Genetic progression model for head and neck cancer: implications for field cancerization. Cancer research 1996;56(11):2488-2492. [PubMed: 8653682]

49. Sanz-Ortega J, Valor C, Saez MC, et al. 3p21, 5q21, 9p21 and 17p13 allelic deletions accumulate in the dysplastic spectrum of laryngeal carcinogenesis and precede malignant transformation. Histology and histopathology 2003;18(4):1053-1057. [PubMed: 12973674]

50. Ishii H, Wang Y, Huebner K. A Fhit-ing role in the DNA damage checkpoint response. Cell cycle (Georgetown, Tex 2007;6(9):1044-1048.

51. Gollin SM. Chromosomal alterations in squamous cell carcinomas of the head and neck: window to the biology of disease. Head \& neck 2001;23(3):238-253. [PubMed: 11428456]

52. Califano J, Westra WH, Meininger G, et al. Genetic progression and clonal relationship of recurrent premalignant head and neck lesions. Clin Cancer Res 2000;6(2):347-352. [PubMed: 10690509]

53. Kresty LA, Mallery SR, Knobloch TJ, et al. Alterations of p16(INK4a) and p14(ARF) in patients with severe oral epithelial dysplasia. Cancer research 2002;62(18):5295-5300. [PubMed: 12234999]

54. Erber R, Conradt C, Homann N, et al. TP53 DNA contact mutations are selectively associated with allelic loss and have a strong clinical impact in head and neck cancer. Oncogene 1998;16(13):16711679. [PubMed: 9582015] 
55. Gonzalez MV, Pello MF, Lopez-Larrea C, et al. Loss of heterozygosity and mutation analysis of the p16 (9p21) and p53 (17p13) genes in squamous cell carcinoma of the head and neck. Clin Cancer Res 1995;1(9):1043-1049. [PubMed: 9816078]

56. Gotte K, Riedel F, Neubauer J, et al. The relationship between allelic imbalance on 17p, p53 mutation and p53 overexpression in head and neck cancer. International journal of oncology 2001;19(2):331336. [PubMed: 11445847]

57. Rodrigo JP, Coto E, Gonzalez MV, Maldonado M, Suarez C. P53 allelic loss and outcome in patients with squamous cell carcinoma of the head and neck. Eur Arch Otorhinolaryngol 2001;258(5):255258. [PubMed: 11548906]

58. Karsai S, Abel U, Roesch-Ely M, et al. Comparison of p16(INK4a) expression with p53 alterations in head and neck cancer by tissue microarray analysis. The Journal of pathology 2007;211(3):314322. [PubMed: 17152048]

59. de Oliveira LR, Ribeiro-Silva A, Zucoloto S. Prognostic impact of p53 and p63 immunoexpression in oral squamous cell carcinoma. J Oral Pathol Med 2007;36(4):191-197. [PubMed: 17391296]

60. Nimeus E, Baldetorp B, Bendahl PO, et al. Amplification of the cyclin D1 gene is associated with tumour subsite, DNA non-diploidy and high S-phase fraction in squamous cell carcinoma of the head and neck. Oral Oncol 2004;40(6):624-629. [PubMed: 15063391]

61. Rousseau A, Lim MS, Lin Z, Jordan RC. Frequent cyclin D1 gene amplification and protein overexpression in oral epithelial dysplasias. Oral Oncol 2001;37(3):268-275. [PubMed: 11287281]

62. Yuan B, Oechsli MN, Hendler FJ. A region within murine chromosome 7F4, syntenic to the human $11 \mathrm{q} 13$ amplicon, is frequently amplified in 4NQO-induced oral cavity tumors. Oncogene 1997;15 (10):1161-1170. [PubMed: 9294609]

63. Zimmermann M, Zouhair A, Azria D, Ozsahin M. The epidermal growth factor receptor (EGFR) in head and neck cancer: its role and treatment implications. Radiation oncology (London, England) 2006;1:11.

64. Grandis JR, Zeng Q, Drenning SD, Tweardy DJ. Normalization of EGFR mRNA levels following restoration of wild-type p53 in a head and neck squamous cell carcinoma cell line. International journal of oncology 1998;13(2):375-378. [PubMed: 9664135]

65. Grandis JR, Chakraborty A, Zeng Q, Melhem MF, Tweardy DJ. Downmodulation of TGF-alpha protein expression with antisense oligonucleotides inhibits proliferation of head and neck squamous carcinoma but not normal mucosal epithelial cells. Journal of cellular biochemistry 1998;69(1):5562. [PubMed: 9513046]

66. Hu G, Liu W, Mendelsohn J, et al. Expression of epidermal growth factor receptor and human papillomavirus E6/E7 proteins in cervical carcinoma cells. Journal of the National Cancer Institute 1997;89(17):1271-1276. [PubMed: 9293917]

67. Rubin Grandis J, Melhem MF, Barnes EL, Tweardy DJ. Quantitative immunohistochemical analysis of transforming growth factor-alpha and epidermal growth factor receptor in patients with squamous cell carcinoma of the head and neck. Cancer 1996;78(6):1284-1292. [PubMed: 8826952]

68. Nelson EG, Grandis JR. Aberrant kinase signaling: lessons from head and neck cancer. Future oncology (London, England) 2007;3(3):353-361.

69. Crowe DL, Hacia JG, Hsieh CL, Sinha UK, Rice H. Molecular pathology of head and neck cancer. Histology and histopathology 2002;17(3):909-914. [PubMed: 12168802]

70. Chen T, Yan W, Wells RG, et al. Novel inactivating mutations of transforming growth factor-beta type I receptor gene in head-and-neck cancer metastases. International journal of cancer 2001;93(5): 653-661.

71. Garrigue-Antar L, Munoz-Antonia T, Antonia SJ, et al. Missense mutations of the transforming growth factor beta type II receptor in human head and neck squamous carcinoma cells. Cancer research 1995;55(18):3982-3987. [PubMed: 7664267]

72. Kim SK, Fan Y, Papadimitrakopoulou V, et al. DPC4, a candidate tumor suppressor gene, is altered infrequently in head and neck squamous cell carcinoma. Cancer research 1996;56(11):2519-2521. [PubMed: 8653689]

73. Muro-Cacho CA, Rosario-Ortiz K, Livingston S, Munoz-Antonia T. Defective transforming growth factor beta signaling pathway in head and neck squamous cell carcinoma as evidenced by the lack of expression of activated Smad2. Clin Cancer Res 2001;7(6):1618-1626. [PubMed: 11410498] 
74. Wang D, Song H, Evans JA, et al. Mutation and downregulation of the transforming growth factor beta type II receptor gene in primary squamous cell carcinomas of the head and neck. Carcinogenesis 1997;18(11):2285-2290. [PubMed: 9395234]

75. Paterson IC, Matthews JB, Huntley S, et al. Decreased expression of TGF-beta cell surface receptors during progression of human oral squamous cell carcinoma. The Journal of pathology 2001;193(4): 458-467. [PubMed: 11276004]

76. Bottinger EP, Jakubczak JL, Haines DC, Bagnall K, Wakefield LM. Transgenic mice overexpressing a dominant-negative mutant type II transforming growth factor beta receptor show enhanced tumorigenesis in the mammary gland and lung in response to the carcinogen 7,12-dimethylbenz-[a]anthracene. Cancer research 1997;57(24):5564-5570. [PubMed: 9407968]

77. Cheng N, Bhowmick NA, Chytil A, et al. Loss of TGF-beta type II receptor in fibroblasts promotes mammary carcinoma growth and invasion through upregulation of TGF-alpha-, MSP- and HGFmediated signaling networks. Oncogene 2005;24(32):5053-5068. [PubMed: 15856015]

78. Honjo Y, Bian Y, Kawakami K, et al. TGF-beta receptor I conditional knockout mice develop spontaneous squamous cell carcinoma. Cell cycle (Georgetown, Tex 2007;6(11):1360-1366.

79. Im YH, Kim HT, Kim IY, et al. Heterozygous mice for the transforming growth factor-beta type II receptor gene have increased susceptibility to hepatocellular carcinogenesis. Cancer research 2001;61(18):6665-6668. [PubMed: 11559531]

80. Jakowlew SB, Moody TW, You L, Mariano JM. Reduction in transforming growth factor-beta type II receptor in mouse lung carcinogenesis. Molecular carcinogenesis 1998;22(1):46-56. [PubMed: 9609100]

81. Kang Y, Mariano JM, Angdisen J, et al. Enhanced tumorigenesis and reduced transforming growth factor-beta type II receptor in lung tumors from mice with reduced gene dosage of transforming growth factor-beta1. Molecular carcinogenesis 2000;29(2):112-126. [PubMed: 11074608]

82. Kanzler S, Meyer E, Lohse AW, et al. Hepatocellular expression of a dominant-negative mutant TGFbeta type II receptor accelerates chemically induced hepatocarcinogenesis. Oncogene 2001;20(36): 5015-5024. [PubMed: 11526486]

83. Lenferink AE, Magoon J, Pepin MC, Guimond A, O'Connor-McCourt MD. Expression of TGF-beta type II receptor antisense RNA impairs TGF-beta signaling in vitro and promotes mammary gland differentiation in vivo. International journal of cancer 2003;107(6):919-928.

84. Siegel PM, Shu W, Cardiff RD, Muller WJ, Massague J. Transforming growth factor beta signaling impairs Neu-induced mammary tumorigenesis while promoting pulmonary metastasis. Proceedings of the National Academy of Sciences of the United States of America 2003;100(14):8430-8435. [PubMed: 12808151]

85. Munoz-Antonia T, Li X, Reiss M, Jackson R, Antonia S. A mutation in the transforming growth factor beta type II receptor gene promoter associated with loss of gene expression. Cancer research 1996;56(21):4831-4835. [PubMed: 8895728]

86. Seijo ER, Song H, Lynch MA, et al. Identification of genetic alterations in the TGFbeta type II receptor gene promoter. Mutation research 2001;483(1-2):19-26. [PubMed: 11600128]

87. Huntley SP, Davies M, Matthews JB, et al. Attenuated type II TGF-beta receptor signalling in human malignant oral keratinocytes induces a less differentiated and more aggressive phenotype that is associated with metastatic dissemination. International journal of cancer 2004;110(2):170-176.

88. Zhu HJ, Burgess AW. Regulation of transforming growth factor-beta signaling. Mol Cell Biol Res Commun 2001;4(6):321-330. [PubMed: 11703090]

89. Osada H, Tatematsu Y, Sugito N, Horio Y, Takahashi T. Histone modification in the TGFbetaRII gene promoter and its significance for responsiveness to HDAC inhibitor in lung cancer cell lines. Molecular carcinogenesis 2005;44(4):233-241. [PubMed: 16163707]

90. Amendt C, Schirmacher P, Weber H, Blessing M. Expression of a dominant negative type II TGFbeta receptor in mouse skin results in an increase in carcinoma incidence and an acceleration of carcinoma development. Oncogene 1998;17(1):25-34. [PubMed: 9671311]

91. Han G, Lu SL, Li AG, et al. Distinct mechanisms of TGF-beta1-mediated epithelial-to-mesenchymal transition and metastasis during skin carcinogenesis. The Journal of clinical investigation 2005;115 (7):1714-1723. [PubMed: 15937546] 
92. Prime SS, Davies M, Pring M, Paterson IC. The role of TGF-beta in epithelial malignancy and its relevance to the pathogenesis of oral cancer (part II). Crit Rev Oral Biol Med 2004;15(6):337-347. [PubMed: 15574678]

93. Schutte M, Hruban RH, Hedrick L, et al. DPC4 gene in various tumor types. Cancer research 1996;56 (11):2527-2530. [PubMed: 8653691]

94. Yan W, Vellucci VF, Reiss M. Smad protein expression and activation in transforming growth factorbeta refractory human squamous cell carcinoma cells. Oncology research 2000;12(3):157-167. [PubMed: 11216674]

95. Riggins GJ, Kinzler KW, Vogelstein B, Thiagalingam S. Frequency of Smad gene mutations in human cancers. Cancer research 1997;57(13):2578-2580. [PubMed: 9205057]

96. Qiu W, Schonleben F, Li X, Su GH. Disruption of transforming growth factor beta-Smad signaling pathway in head and neck squamous cell carcinoma as evidenced by mutations of SMAD2 and SMAD4. Cancer letters 2007;245(1-2):163-170. [PubMed: 16478646]

97. Suganuma T, Kawabata M, Ohshima T, Ikeda MA. Growth suppression of human carcinoma cells by reintroduction of the p300 coactivator. Proceedings of the National Academy of Sciences of the United States of America 2002;99(20):13073-13078. [PubMed: 12237408]

98. Todd R, McBride J, Tsuji T, et al. Deleted in oral cancer-1 (doc-1), a novel oral tumor suppressor gene. Faseb J 1995;9(13):1362-1370. [PubMed: 7557027]

99. Shintani S, Ohyama H, Zhang X, et al. p12(DOC-1) is a novel cyclin-dependent kinase 2-associated protein. Molecular and cellular biology 2000;20(17):6300-6307. [PubMed: 10938106]

100. Matsuo K, Shintani S, Tsuji T, et al. p12(DOC-1), a growth suppressor, associates with DNA polymerase alpha/primase. Faseb J 2000;14(10):1318-1324. [PubMed: 10877824]

101. Todd R, Hinds PW, Munger K, et al. Cell cycle dysregulation in oral cancer. Crit Rev Oral Biol Med 2002;13(1):51-61. [PubMed: 12097237]

102. Tsuji T, Duh FM, Latif F, et al. Cloning, mapping, expression, function, and mutation analyses of the human ortholog of the hamster putative tumor suppressor gene Doc-1. The Journal of biological chemistry 1998;273(12):6704-6709. [PubMed: 9506968]

103. Shintani S, Mihara M, Terakado N, et al. Reduction of p12DOC-1 expression is a negative prognostic indicator in patients with surgically resected oral squamous cell carcinoma. Clin Cancer Res 2001;7 (9):2776-2782. [PubMed: 11555592]

104. Peng H, Shintani S, Kim Y, Wong DT. Loss of p12CDK2-AP1 expression in human oral squamous cell carcinoma with disrupted transforming growth factor-beta-Smad signaling pathway. Neoplasia (New York, N.Y 2006;8(12):1028-1036.

105. Figueiredo ML, Kim Y, St John MA, Wong DT. p12CDK2-AP1 gene therapy strategy inhibits tumor growth in an in vivo mouse model of head and neck cancer. Clin Cancer Res 2005;11(10):3939_ 3948. [PubMed: 15897596]

106. Johnstone S, Logan RM. Expression of vascular endothelial growth factor (VEGF) in normal oral mucosa, oral dysplasia and oral squamous cell carcinoma. International journal of oral and maxillofacial surgery 2007;36(3):263-266. [PubMed: 17141472]

107. Bowden J, Brennan PA, Umar T, Cronin A. Expression of vascular endothelial growth factor in basal cell carcinoma and cutaneous squamous cell carcinoma of the head and neck. Journal of cutaneous pathology 2002;29(10):585-589. [PubMed: 12453295]

108. Mineta H, Miura K, Ogino T, et al. Prognostic value of vascular endothelial growth factor (VEGF) in head and neck squamous cell carcinomas. British journal of cancer 2000;83(6):775-781. [PubMed: 10952783]

109. Walsh JE, Lathers DM, Chi AC, et al. Mechanisms of tumor growth and metastasis in head and neck squamous cell carcinoma. Current treatment options in oncology 2007;8(3):227-238. [PubMed: 17712533]

110. Leivonen SK, Ala-Aho R, Koli K, et al. Activation of Smad signaling enhances collagenase-3 (MMP-13) expression and invasion of head and neck squamous carcinoma cells. Oncogene 2006;25 (18):2588-2600. [PubMed: 16407850]

111. Minter HA, Eveson JW, Huntley S, Elder DJ, Hague A. The cyclooxygenase 2-selective inhibitor NS398 inhibits proliferation of oral carcinoma cell lines by mechanisms dependent and independent 
of reduced prostaglandin E2 synthesis. Clin Cancer Res 2003;9(5):1885-1897. [PubMed: 12738747]

112. Miyazaki H, Patel V, Wang H, et al. Growth factor-sensitive molecular targets identified in primary and metastatic head and neck squamous cell carcinoma using microarray analysis. Oral Oncol 2006;42(3):240-256. [PubMed: 16266819]

113. Sumitani K, Kamijo R, Toyoshima T, et al. Specific inhibition of cyclooxygenase-2 results in inhibition of proliferation of oral cancer cell lines via suppression of prostaglandin E2 production. J Oral Pathol Med 2001;30(1):41-47. [PubMed: 11140899]

114. Pak AS, Wright MA, Matthews JP, et al. Mechanisms of immune suppression in patients with head and neck cancer: presence of CD34(+) cells which suppress immune functions within cancers that secrete granulocyte-macrophage colony-stimulating factor. Clin Cancer Res 1995;1(1):95-103. [PubMed: 9815891]

115. Young MR, Cigal M. Tumor skewing of CD34+ cell differentiation from a dendritic cell pathway into endothelial cells. Cancer Immunol Immunother 2006;55(5):558-568. [PubMed: 16025265]

116. Young MR. Tumor skewing of CD34+ progenitor cell differentiation into endothelial cells. International journal of cancer 2004;109(4):516-524.

117. Choi HR, Tucker SA, Huang Z, et al. Differential expressions of cyclin-dependent kinase inhibitors (p27 and p21) and their relation to p53 and Ki-67 in oral squamous tumorigenesis. International journal of oncology 2003;22(2):409-414. [PubMed: 12527941]

118. Kudo Y, Kitajima S, Ogawa I, Miyauchi M, Takata T. Down-regulation of Cdk inhibitor p27 in oral squamous cell carcinoma. Oral Oncol 2005;41(2):105-116. [PubMed: 15695111]

119. de Moraes RV, Oliveira DT, Landman G, et al. E-cadherin abnormalities resulting from CPG methylation promoter in metastatic and nonmetastatic oral cancer. Head \& neck. 2007

120. Kurtz KA, Hoffman HT, Zimmerman MB, Robinson RA. Decreased E-cadherin but not beta-catenin expression is associated with vascular invasion and decreased survival in head and neck squamous carcinomas. Otolaryngol Head Neck Surg 2006;134(1):142-146. [PubMed: 16399195]

121. Mattijssen V, Peters HM, Schalkwijk L, et al. E-cadherin expression in head and neck squamouscell carcinoma is associated with clinical outcome. International journal of cancer 1993;55(4):580 585.

122. Kim ES, Kies M, Herbst RS. Novel therapeutics for head and neck cancer. Current opinion in oncology 2002;14(3):334-342. [PubMed: 11981281] 